\title{
TOBAT SEBAGAI SEBUAH TERAPI (KAJIAN PSIKOTERAPI ISLAM)
}

\author{
Erba Rozalina Yulianti \\ UIN Sunan Gunung Djati Bandung \\ Kontak: Jln. Kemang Pratama 2 Jl. Anggrek 4 Blok AO no 19 Bekasi, Hp 081310289372
}

\begin{abstract}
This paper will discuss how the concept of repentance ( tobat) in Islam can be used as therapy for human souls who are mired in a life of vice and sin. Either a sin will be cause a negative behaviour or negative thought. It is obvious that when someone is doing a lot of sin, so all the thoughts, feelings and behaviors are getting disorder. Based on this effect a sin will disturb the balance of man thinking, feeling and behavior. So it may not find tranquility and peace of mind. Indeed, it appears the anxiety and restlessness that lead to the emergence of a more severe psychological symptoms. Tobat which has a combination of psychological functions can fill the rest of Islamic Psychoterapy. This is understandable because Tobat process has formed as a variety of positive psycholocical functioning. They are: 1) Awareness to change behavior, 2) Self evaluation ( comfession), 3) Positve feelings ( remorse ), 4). Positive attitudes ( commitment), 5). Change of behavior consitently.
\end{abstract}

\section{KEY WORDS}

Tobat; Sins; Islamic Therapy; Behavior; Thought

DOI: https://doi.org/10.15575/saq.v1i2.1429

\section{A. PENDAhULUAN}

Jika kita memperhatikan kehidupan para artis, baik yang masih aktif maupun tidak, maka kesan pertama yang akan muncul adalah berbagai pandangan kehidupan glamor, serba mewah, night club, dan lain sebagainya. Betulkan gaya hidup artis memang hanya sedemikian itu saja? Jawabannya ternyata tidak. Hal ini tidak berlaku pada sebagian artis, contohnya, kehidupan Hari Mukti, mantan penyanyi rok era 80-an yang kini aktif berdakwah, dan mengajak kepada jalan agama. Hari Mukti yang terkenal dengan lagunya "Hanya Satu Kata" memilih jalan hidup agama dengan mengambil aktivitas sebagai pendakwah sejak tahun 90-an. Menurutnya, dunia artis lebih banyak mudharatnya daripada maslahah dan manfaatnya.

Proses transformasi diri Hari Mukti diawali dengan kesadarannya bahwa hidup bergelimang harta tidak menjamin dirinya menjadi bahagia. Dalam setiap dakwahnya beliau selalu bercerita bahwa dulu hidupnya bergelimang harta dan terkenal, namun hidupnya resah dan penuh dengan rasa sakit hati. Perusahaan gulung tikar satu persatu da perusahaannya hancur. Kemudian beliau rajin menghadiri pengajian di Hizbur Tahrir dan meninggalkan dunia artis. Disana beliau mengakui dosa dan menyesali kesalahan yang telah banyak dilakukannya. Sampai saat ini beliau berkomitmen untuk selalu istiqomah dalam menjalani kehidupan yang Islami. Hari Mukti telah bertobat. Alhasil kini beliau merasa hidupnya lebih tenang dan lebih berkah, walaupun tidak sekaya dulu. Kang Hari (panggilan akrabnya) menegaskan bahwa nikmat yang paling berharga dan paling penting adalah nikmat iman dan nikmat beribadah kepada Allah SWT.

Makalah ini akan membahas tentang bagaiman konsep tobat dalam Islam dapat dijadikan terapi jiwa bagi manusia yang merasa terjerumus dalam kehidupan yang penuh maksiat dan dosa. 


\section{B. DOSA DAN KONDISI PSIKOLOGIS MANUSIA}

Dosa dan kesalahan merupakan masalah penting yang menjadi fokus perhatian dalam ajaran dan nilai-nilai Islam karena keduanya menyangkut hubungan antara manusia dengan manusia,manusia dengan lingkungannya, manusia dengan Tuhannya dan manusia dengan dirinya sendiri. Bahkan dosa dan kesalahan juga berkaitan dengan ketenteraman, kesejahteraan dan kebahagiaan seseorang atau ketidaktenangan, penderitaan dan ketidakbahagiaan (kesengsaraan).

Rasulullah SAW menyampaikan bahwa "Dosa merupakan sesuatu yang terasa menggelisahkan jiwa dan kamu tidak mau menampakkannya kepada orang lain. Selanjutnya Beliau menambahkan bahwa perbuatan baik adalah perbuatan yang membuat jiwa tenteram dan hati menjadi tenang, sedangkan perbuatan dosa adalah perbuatan yang menjadikan jiwa goncang dan hati gusar, sekalipun kamu mendapatkan nasehat dari ahli fatwa. (HR.Imam Ahmad). ${ }^{1}$

Dari hadits diatas dapat dipahami bahwa perbuatan dosa sangat berhubungan dengan kondisi psikologis seseorang. Dosa dan kesalahan dalam bentuk apapun, baik yang berhubungan dengan Allah, dengan lingkungan dan sesama manusia serta dengan dirinya sendiri akan membuat ketidaktenangan, kegelisahan dan perasaan bersalah. Bahkan pada beberapa kasus tertentu seseorang yang dengan sengaja (sadar) melakukan perbuatan jelek akan berusaha menyembunyikannya dari orang lain dan hal ini dapat merangsang kegelisahan dan stress yang berkepanjangan karena membutuhkan energi untuk menghindarkan diri agar tidak diketahui oleh orang lain.

1 Imam an-Nawawi dkk, Syarah Hadits Arba'in: Kompilasi Empat Ulama Besar (Jakarta: Niaga Swadaya,2008), 299.

2 Ibn Qayyim al-Jauziah, Al-Da' wa al-Dawa': alJawab al-Kaafi li-Man Sa'ala 'an al-Dawa' al-Syafi,
Dosa (pelanggaran) yang dilakukan berhubungan dengan orang lain tentunya akan memberikan dampak psiko-sosial yang lebih berat dibandingkan dengan pelanggaran yang berhubungan dengan Allah maupun dengan dirinya sendiri. Hal ini dikarenakan adanya kewajiban mengembalikan hak-hak orang lain yang telah diambil atau dirusak dan membutuhkan kerelaannya sebagai syarat ampunan dari Allah SWT. Disamping itu pelanggaran yang berhubungan dengan orang lain akan mengganggu pola hubungan atau komunikasi antara sesama manusia dan pada akhirnya akan dapat mengganggu sistem social kemasyarakatan yang telah ada.

Meskipun ada perbedaan kondisi psikologis antara dosa (pelanggaran) yang dilakukan seseorang berhubungan dengan Allah, sesama manusia dan lingkungannnya serta dirinya sendiri, pada hakekatnya setiap dosa yang dilakukan manusia akan meninggalkan bekas (noda hitam) dalam kalbunya. Semakin banyak noda hitam yang melekat dalam kalbu (qalb) sehingga akan mengotori kejernihan hatinya. ${ }^{2}$

Kotornya hati akibat dosa yang dilakukan akan berpengaruh kuat terhadap munculnya perilaku negatif seseorang karena hati (qalb) merupakan raja yang dapat memerintahkan segala bentuk perilaku yang akan muncul. ${ }^{3}$ Begitu pula dengan emosi dan pikiran negatif lainnya yang muncul dapat menganggu kejernihan perasaan dan pikiran seseorang. Nyatalah bahwa ketika seseorang banyak melakukan dosa (pelanggaran) maka seluruh pikiran, perasaan dan perilakunya mengalami gangguan (tidak sesuai dengan fitrahnya). Ia akan semakin jauh dari nilai-nilai agama dan norma kesusilaan tanpa ia sadari serta lambat laun akan menjauhkan dirinya dari kesadaran untuk kembali kepada sistem nilai dan norma yang baik.

Alih Bahasa Fauzy Bahresy (Jakarta: Serambi Ilmu Semesta,2004), 31.

3 Abu Usamah Salim bin 'Ied Al-Hilali, Syarah Riyadhus Shalihin, Alih Bahasa M.Abdul Ghoffar (Jakarta: Pustaka Imam Al-Syafi;I, 2005), 465. 
Melihat kenyataan ini maka perbuatan dosa yang dilakukan seseorang akan menganggu keseimbangan pola pikir, perasaan dan perilaku seseorang, sehingga tidak dijumpai ketentraman dan ketenangan batin. Justru yang muncul adalah kegelisahan dan ketidaktenangan yang mengarah pada munculnya gejala psikologis yang lebih parah (berat). Kondisi ini apabila terus dipertahankan (qalbun mayyit) dapat memunculkan penyakit jiwa (anti sosial dan spiritual) sehingga seseorang tidak dapat lagi membedakan antara sesuatu yang baik dan buruk. Bahkan sudah terpecahnya kepribadian (disharmonisasi pikiranperasaan-perilaku) dapat membawa penyakit jiwa yang berat.

\section{TOBAT}

\section{Pengertian Tobat}

Pengertian tobat menurut bahasa, oleh AlGhazali diartikan dengan "kembali" (ruju'), yaitu kembali dari kemaksiatan kepada ketaatan, kembali dari jalan yang jauh ke jalan yang dekat. ${ }^{4}$ Imam Haramain ( Abdul Ma'ali Al-Juwaini) mengatakan tobat itu ialah meninggalkan keinginan untuk melakukan kejahatan seperti yang pernah dilakukannya karena membesarkan Allah SWT dan menjauhkan diri dari kemurkaannya. ${ }^{5}$ Dalam pengertian syariat, tobat adalah dari perbuatan dosa, baik itu dosa kecil maupun dosa besar. Pengertian dosa disini adalah karena melanggar ketentuan-ketentuan Allah, yaitu meninggalkan apa yang diperintahkan Allah dan mengerjakan apa yang dilarang oleh Allah. ${ }^{6}$

Tobat dalam ajaran Islam memiliki pengertian yang sangat luas karena tobat menyangkut penataan kembali kehidupan manusia yang sudah berantakan dan

4 Imam Al-Ghazali, Mukhtashar Ihya' 'Ulumuddin,Cetakan I ( Beirut: 1990 Muassah AlKutub Al-Tsaqafiyah), 72.

5 Lihat dalam Abdul Manan bin Muhammad Sobari, Keagungan Rajab dan Sya'ban (Jakarta: Republika, 2006),12. perbaikan kembali mental seseorang yang sudah rusak akibat dosa yang diperbuat. Anjuran dan perintah tobat banyak kita jumpai dalam Al-Quran dan Hadits bahkan keutamaannya juga dibahas dalam ilmu syari;ah, tasauf dan akhlak. Tobat dapat diartikan meminta ampun kepada Allah atas seg la perbuatan dosa dan kesalahannya melebihi dari "istighfar". Tobat juga diartikan sebagai pengakuan, penyesalan dan meninggalkan dosa serta berjanji tidak mengulangi perbuatan dosa tersebut. Tobat bermakna telah meninggalkan perbuatan dosanya dan Allah telah mengampuni dan menyelamatkannya dari kemaksiatan. Tobat pada hakikatnya mempunyai 3 (tiga) makna yang saling berurutan yaitu mengandung pengetahuan dan kesadaran ('ilm), kondisi hati (hal) dan tindakan (fi'il). ${ }^{7}$ Makna pertama ( 'ilm) adalah timbulnya pengetahuan dan kesadaran akan besarnya bahaya perbuatan dosa yang ia lakukan. Apabila telah muncul pengetahuan dan kesadaran maka dalam hatinya akan merasa sedih dan takut kehilangan sesuatu yang dicintainya sehingga menimbulkan penyesalan yang teramat dalam. Jika perasaan ini menguasai hatinya maka akan timbul kehendak atau keinginan untuk melakukan sesuatu perbuatan yang berkaitan dengan masa sekarang yaitu segera meninggalkan perbuatan dosa selama-lamanya, berkaitan dengan masa lampau yaitu cepat-cepat mengerjakan kembali kebaikan-kebaikan yang pernah ditinggalkan atau memperbaikinya kembali sepanjang masih dapat diperbaiki. Dengan demikian tobat dapat diartikan sebagai kesadaran yang diikuti dengan penyesalan dan keinginan kuat untuk meninggalkan perbuatan dosa dan berupaya memperbaiki kesalahan masa lalu.

6 Al-Qozin, Sunan Ibn Majah, Jilid I, (Mesir: Darul Fikr.t.t.)659.

7 Afif Abdullah Fatah Thabbarah, Dosa dalam Pandangan Islam (Bandung: Risalah, 1986), 23. 


\section{Syarat-syarat Tobat}

Secara terminologis, tobat itu mencakup tiga syarat, ${ }^{8}$ yaitu meninggalkan perbuatan dosa, menyesali perbuatannya, dan bertekad untuk tidak akan melakukannya kembali.

Menurut ketentuan syariat, "syarat melakukan tobat adalah adanya perasaan menyesal atas dosa yang telah diperbuat". ${ }^{9}$ Kemudian membaca "istighfar", yaitu memohon ampunan kepada Allah atas dosanya tersebut. Sesudah itu harus bertekad yang kuat untuk tidak mengulangi lagi perbuatandosa serupa. Kalau dosanya berkaitan dengan sesama manusia, maka terlebih dahulu ia harus islah dulu kepada orang yang bersangkutan.

Salah satu unsur penting dari tobat adalah rasa penyesalan. Sebab rasa ini mempunyai pengaruh yang sangat besar di dalam merubah sikap seseorang dari keadaan jelek menjadi baik. Tobat adalah penyesalan yang benar, dan tobat mendorong seseorang untuk merubah tingkah lakunya yang dipenuhi dengan dosa menjadi bersih dan baik kembali.

\section{Tingkatan-tingkatan Tobat}

Ada beberapa tingkatan dalam tobat, yaitu: menurut kelangsungan tobatnya, menurut tingkatan kelompok, dan menurut waktunya.

a. Penggolongan orang yang bertobat menurut kelangsungan tobatnya dan sikapnya sesudah itu dapat dibagi menjadi empat golongan, yaitu: ${ }^{10}$

Pertama: Orang yang fitrahnya sehat, mempunyai kemauan keras terhadap perkara kebaikan. Kalau terjerumus kepada perbuatan dosa, maka ia akan menyesal dan bertobat dengan selalu berbuat keutamaan serta berpaling dari perbuatan rendah. Tobat orang semacam itu dinamakan dengan

8Afif Abdullah Fattah Thabbarah, Dosa Dalam Pandangan Islam, (Bandung: Risalah, 1986), 27.

9Muhaimin Aziz, Majalah Sufi, Edisi 28 Desember 2003, 18.
"Tobat Nasuha" atau mempunyai kemantapan dalam tobatnya (istiqomah).

Kedua: Seseorang yang syahwatnya lebih kuat daripada jiwanya, dan lebih mendalam dalam hatinya. Jika orang tersebut menuruti hawa nafsunya, kemudian melakukan suatu perbuatan maksiat, maka dorongan-dorongan Ilahi akan bangkit dan memeranginya, dan mencela dirinya hingga dapat menang dan memaksa dorongan nafsu tunduk padanya. Setelah itu ia tidak akan terjerumus ke dalam perbuatan durhaka. Orang-orang sebagaimana di atas itu adalah orang yang berhak mendapatkan janji baik dari Allah swt, sebagaimana firman Allah dalam surat al-Najm ayat 32 yang artinya : Orang-orang yang mendapatkan kebaikan yaitu yang menjauhi dosa-dosa besar dan beberapa kemaksiatan, kecuali yang hanya merupakan lintasan dalam hati. Sesungguhnya Tuhanmu adalah amat luas pengampunan-Nya. ${ }^{11}$

Ketiga: Seseorang yang mempunyai kapabilitas kuat dalam mujahadah untuk menjauhi dosa-dosa besar dan segala macam perbuatan fahisyah (zina), tetapi tidak untuk dosa-dosa kecil. Di dalam dirinya selalu terjadi peperangan antara kemauan untuk menetapi perbuatan dosa kecil dan dorongan Ilahi yang merupakan pertanda keimanan. Maka peperangan itu silih berganti di dalam jiwanya (terkadang imannya yang menang, terkadang dorongan nafsunya), sebagaimana firman Allah dalam surat Ali Imran ayat 135 yang artinya: "Orang-orang yang memperoleh bahagia adalah orang-orang yang apabila melakukan keburukan atau menganiaya dirinya sendiri, lalu segera ingat kepada Allah, kemudian memohon pengampunan dari dosa-dosa mereka itu”.

Keempat: Orang yang melakukan dosa, kemudian ia bertobat dan minta ampun tetapi ia melakukan perbuatan dosa itu lagi, dan kembali mencela dirinya, menyesal dan

10Ahmad Mustafa al-Maraghi, Terjemah Tafsir al-Maraghi, Vol. 4, (Semarang: Toha Putra, 1993), 376.

11 Al-Quran dan Terjemahnya, Departemen Agama RI. 
minta ampun. Demikianlah seterusnya. Orang-orang seperti ini berada pada derajat paling bawah orang-orang yang bertobat, sebagaimana firman Allah dalam surat AlTaubah ayat 102 yang artinya: "Ada pula orang-orang lain yang sudah mengakui dosa-dosanya, tetapi mereka itu suka mencampurkan amalan baiknya dengan amalan buruknyaOrang yang bertobat menurut tingkatan kelompoknya:

Pertama: Tobat umum: yaitu tobat orang kebanyakan atau masyarakat pada umumnya. Ketika orang itu melakukan dosa maka dia langsung bertobat, setelah dia sadar akan perbuatannya.

Kedua: Tobat khusus (khass), yaitu tobat orang-orang ma'shum (suci, bebas dari kesalahan dan dosa). Tobat ini dilakukan oleh Nabi Adam as dan Nabi-nabi yang lain.

Ketiga: Tobat khususnya khusus (ashkhass), yaitu tobat yang menempuh jalan suluk. Tobat ini adalah tobat yang dilakukan oleh Rasulullah saw sebagaimana haditsnya "Sungguh, hal-hal ragawi telah membayangbayangi hatiku, dan karenanya aku meminta ampun kepada Allah tujuh puluh kali setiap hari".

Tobat tersebut sesuai dengan pernyataan Dzun Nun al-Mishry yaitu "tobat di kalangan publik itu dari dosa, tobat di kalangan khawash itu dari alpa, dan tobat para rasul dan nabi itu karena tidak mendekatkan diri kepada Allah". ${ }^{12}$

b. Tobat menurut tingkatan waktunya: Pertama: Yang berhubungan dengan masa lalu. Tobat berkaitan dengan penyesalan terhadap dosa-dosa yang telah dilakukannya, dan perbuatan-perbuatan yang menunjukkan penyesalan tersebut. Perbuatan tersebut menyangkut tiga aspek, yaitu yang berhubungan dengan Allah, yang berhubungan dengan diri sendiri, dan yang berhubungan dengan orang lain.

Kedua: Yang berhubungan dengan masa kini. Aspek tobat yang berhubungan dengan masa kini yaitu menahan diri dari melakukan

12Hamka, Tasawuf: Perkembangan dan Pemurniannya, (Jakarta: Pustaka Panjimas, 1993), 91. dosa dan memberikan kompensasi tertentu terhadap kesalahan yang telah dilakukan.

Ketiga: Yang berhubungan dengan masa depan yaitu bertekad untuk tidak melakukan dosa lagi di masa mendatang dan bersabar dengan tekadnya tersebut.

\section{NILAI-NILAI PSIKOLOGIS DALAM TOBAT}

Tobat merupakan usaha manusia untuk membebaskan dirinya dari pengaruh perbuatan dosa dan menata kembali kehidupannya. Tobat merupakan usaha mandiri yang dilakukan individu untuk membebaskan dirinya dari perasaan bersalah dan keinginan sendiri untuk memperbaiki keadaan. Permohonan ampunan dalam perilaku tobat dianjurkan untuk setiap dosa yang telah dilakukan, sehingga manusia menyadari dengan sebenar-benarnya tentang konsekuensi pertobatan terhadap dosa yang telah ia lakukan yaitu tidak mengulangi kembali kehidupannya. Tobat merupakan usaha mandiri yang dilakukan individu untuk membebaskan dirinya dari perasaan bersalah dan keinginan sendiri untuk memperbaiki keadaan.

Permohonan ampunan dalam perilaku tobat dianjurkan untuk setiap dosa yang telah dilakukannya, sehingga manusia menyadari dengan sebenar-benarnya tentang konsekuensi pertobatan terhadap dosa yang telah ia lakukan yaitu tidak mengulangi kembali perbuatan tersebut. Pada hakekatnya tobat jika dilihat dari aspek kejiwaan adalah suatu kombinasi dari fungsi-fungsi kejiwaan yang mampu merevitalisasi kondisi psikologis manusia. Adapung nilai-nilai psikologis tersebut adalah:

\section{Kesadaran}

Kesadaran adalah pikiran yang terintegrasi dan terorganisasi berupa pengalaman subjektif, emosi dan proses mental seseorang. ${ }^{13}$ Kesadaran diri adalah keadaan dimana seseorang secara subjektif

13 Carole Wade \& Carol Tavris, Psikologi, Edisi 9, Jilid (Jakarta: Erlangga, 2007), 179. 
dapat memahami dirinya sendiri dengan setepat-tepatnya, dan mengenal dengan sadar mengenai pikiran, perasaan dan evaluasi diri yang ada dalam dirinya. Dalam tobat, seseorang yang akan melangkan pada proses pertobatan yang sesungguhnya telah mempunyai pengetahuan yang sebenarbenarnya tentang keburukan akibat perbuatan yang telah dilakukan. Pengetahuan ini berasal dari pengalaman hidup yang telah dijalaninya, perjalanan hidup orang lain yang mempunyai pengalaman perilkau yang sejenis dan bimbingan spiritual dari seseorang yang mengingatkan akibat perilaku tersebut. Kedalam pengetahuan yang telah dimiliki ini akan membawa pada tingkat kesadaran sepenuhnya tentang buruknya perilaku dosa dan maksiat, penerimaan diri yang sesungguhnya, menata kembali kehidupannya, mengadakan integrasi diri dengan orang lain dan lingkungannya, sehingga pada akhirnya dapat menemukan keterpaduan dirinya kembali setelah terpecah akibat perilaku dosa yang tidak ia sadari sebegitu besar pengaruhnya dalam kehidupan. Kesadaran ini pula yang akan menuntun seseorang untuk memahami keberadaan dirinya dan berfikir tentang tuhannya untuk segera bertobat.

\section{Pengakuan dosa}

Dalam bahasa Psikoanalisa Freud, kondisi pengakuan dosa dikenal dengan istilah abtraction, yaitu suatu proses menghilangkan ketegangan jiwa atau pelepasan suatu perasaan yang terpendam dan pengalaman yang tidak disenangi dalam hidup melalui pengungkapan kembali dengan lisan, tulisan, maupun hati apa yang menjadi kegundahan dan sumber kegelisahan tersebut. Freud mengatakan bahwa jiwa setiap pembuat kesalahan (neurosis) merasa tertekan oleh

14 K. Bertens,Psikoanalisis Sigmund Freud, (Jakarta: Gramedia Pustaka Utama, 2006), 185.

15 Imam al-Ghazalial, Mukhtashar Ihya' 'Ulumuddin,Cetakan I ( Beirut: 1990 Muassah AlKutub Al-Tsaqafiyah),83. suatu beban rahasia. Dengan memberinya kesempatan mengutarakan isi hatinya dia akan terbebas dari tekanan dan akhirnya ia akan merasa lega. Pengakuan dosa dapat mempunyai efek psikologis yaitu perasaan lega. ${ }^{14}$

Tak jauh berbeda dengan pendapat Freud, para Sufi mengatakan bahwa pengakuan dosa atau al I'tiraf merupakan suatu unsur penting dalam proses pertobatan. pengakuan dosa adalah pengungkapan kembali perbuatan dosa dan kesalahan yang pernah dilakukan secara jujur dan benar. Menurut al-Ghazali, dalam pengakuan dosa (al-I'tiraf bi Zhulm) orang akan mengungkapkan dosa dan kesalahan yang ia lakukan secara sadar. ${ }^{15} \mathrm{Abu}$ Laits Samarqandi menyarankan agar dalam pengakuan dosa ini disebutkan sifat (jenis)n dosa yang telah diperbuatnya sebagai hasil perenungan atas tingkat kesadaran yang telah dimiliki. ${ }^{16}$ Pengakuan dosa yang dilakukan secara benar dan jujur sangat penting dalam usaha mendapatkan kelegaan batin karena ini berarti ia telah merelakan perilaku dosa tersebut diakui secara lisan maupun batin sehingga akan menghilangkan tekanan kegelisahan akibat simpanan dosa tersebut.

\section{Penyesalan}

Nilai psikologi yang lain dalam proses pertobatan adalah menyesali perbuatan dosa yang telah diperbuat dan menyesali telah meninggalkan berbagai perilaku baik lainnya seiring dengan perjalanan waktu yang telah berlalu. Al-Ghazali membedakan pengakuan dosa dengan penyesalan, kalau pengakuan dosa diungkapkan secara sadar sedangkan penyesalan (al-nadam) orang menginsyafi atau menyesali dirinya karena telah berbuat dosa dan salah, serta berniat untuk memperbaikinya. ${ }^{17}$ Penyesalan memiliki

16 Al-Faqih Abul Laits Assamarqandi, Tanbihul Ghafilin, Alih Bahasa, Salim Nabhan (Surabaya: AlManar,1990), 182.

17 Imam Al-Ghazali, Mukhtashar Ihya' 'Ulumuddin,Cetakan I ( Beirut: 1990 Muassah AlKutub Al-Tsaqafiyah), 60. 
nilai dinamis yang tidak berhenti pada masa lalu tetapi masa sekarang dan masa yang akan datang. Artinya penyesalan tersebut akan mengarahkan dirinya untuk berbuat yang lebih baik dengan menguatkan dan menyempurnakan keimanan dan ketaqwaan. Penyesalan seperti ini dipahami dapat meluruskan kepribadian seseorang karena adanya sinkronisasi afeksi antara pengalaman masa lalu, masa sekarang dan masa yang akan datang.

\section{Komitmen}

Richard mengatakan bahwa komitmen adalah sebuah usaha mengungkapkan apa yang penting bagi seseorang dan apa yang dinilai penting bagi mereka. Nilai-nilai yang terkandung dalam prinsip komitmen adalah nilai kognitif. ${ }^{18}$ Komitmen mendasari pilihan orang berbuat atau mempersiapkan diri untuk mempertahankan dan mencapai tujuan yang diinginkan. Sikap yang dimiliki seseorang untuk tetap berada dalam lingkungannya sebagai hasil interaksi pemahaman dan pengalamannya.

Penyesalan yang telah dialami oleh seseorang akan memunculkan keinginan kuat untuk bertahan pada suatu kondisi tertentu yaitu keinginan untuk tidak mengulangi perbuatan dosa yang pernah dilakukan, keinginan untuk lebih menngkatkan keimana dan ketaqwaan (berpedoman pada nilai moral dan agama) serta keinginan untuk memperbaiki diri melalui peningkatan amal ibadah yang selama ini banyak ditinggalkan. Komitmen ini memungkinkan seseorang tidak larut dalam penyesalan akibat dosa yang ia perbuat tetapi keluar dari diri yang sebelumnya menjadi diri baru yang seutuhnya. Dan akhirnya komitmen akan mendorong seseorang berperilaku positif menuju hasil yang diinginkan.

18 Richard S. Lazarus, Susan Folkman, Stress, Apprasial and Coping, (New York: Springer, 1984),56.

\section{E. TOBAT DAN PSIKOTERAPI ISLAMI}

Seiring perkembangan dunia modern saat ini banyak dijumpai tragedi-tragedi kemanusia dan kehidupan modern yang menempatkan manusia posisi sebagai pelaku dan korban tragedy tersebut. Kemajuan yang tekah dicapai saat ini seharusnya membawa kepada kemajuan kehidupan pribadi manusia bukan sebaliknya. Artinya kebahagiaan dan ketenteraman semakin sulit dijangkau oleh orang-orang yang maju. Kesulitan material (harta duniawi) kini diganti dengan kesukaran mental (psikologis) sehingga menimbulkan beban jiwa yang semakin berat. Kegelisahan, ketenangan, ketidakpastian dan tekanan perasaan lebih terasa menekan sehingga mengurangi kebahagiaan. Kondisi ini telah lama bertahan akibat kebutuhan hidup yang semakin meningkat, sikap individualistic dan egois, persaingan gaya hidup dan didukung oleh keadaan yang tidak stabil.

Individu yang terlarut dalam kondisi ini dapat dipastikan karena kehilangan control atas kehidupannya sendiri yang bersumber hilangnya nilai-nilai spiritual dan visi keilahian. Orang yang telah lupa akan visivisi hidup yang sebenarnya akan makin terpuruk dengan perilaku negative yang tidak disadari telah dikerjakannya tersebut. Seseorang tidak dapat membedakan mana yang benar (dikehendaki oleh Tuhan) dan mana yang salah (diarahkan oleh syahwat). Keadaan ini dapat membahayakan kehidupan seseorang karena akan terjerumus pada perilaku bebas tidak berketuhanan (beragama). Ia tidak lagi dapat membedakan perilaku positif dan negatif yang berhubungan dengan Tuhannya, sesame manusia (lingkungannya) dan dengan dirinya sendiri, sehingga perilakunya tidak berarah tujuan. Kondisi diatas merupakan cermin ketika seseorang dan masyarakatnya telah terjebak dalam perilaku dosa dan salah yang berkepanjangan. 
Dosa membuat hati manusia menjadi kotor, kusam, dan hitam, padahal hati berfungsi sebagai cermin diri guna mengetahui hakekat kebenaran. Dapat dibayangkan apabila hati (cermin) ini kotor oleh perbuatan dosa dan maksiat maka manusia tidak dapat lagi membedakan kebenaran dan keburukan, sehingga manusia akan menderita, hilangnya rasa bahagia marah, dan,cinta dan sayang serta timbulnya rasa benci, dengki, sombong,dan gelisah.

Perasaan, pikiran dan tngkah laku yang negative ini memiliki muara dari perbuatan dosa dan kesalahan yang dilakukan oleh seseorang dengan objek dan kapasitas manapun. Dosa yang tergolong besar atau dosa kecil yang dilakukan terus menerus tentunya akan memberikan dampak yang lebih berat dibandingan dosa kecil atau yang langsung disertai dengan perbuatan baik (proses pertobatan). "Dan bertobatlah kamu sekalian kepada Allah, hai orang-orang yang beriman supaya kamu beruntung"19. Sedangkan hadits Nabi menyebutkan "Ikutilah segera perbuatan buruk dengan kebaikan, agar kamu menghapuskannya”.

Dengan demikian dapat dikatakan bahwa perbuatan dosa dan salah yan mengakibatkan munculnya pikiran, perasaan dan perilaku negatif dapat diminimalkan dan bahkan dihapuskan dengan bersegera meminta ampunan dan bertobat kepada Allah. Ketika tobat diterima dan ampunan diberikan maka hati yang tadinya kotot lambat laun akan kembali bersih dan dapat dijadikan cermin kemali sehingga seseorang dapat membedakan mana yang benar dan mana yang salah.

\section{F. FUNGSI TOBAT DALAM PSIKOTERAPI ISLAM}

Secara umum menurut Brammer, fungsi psikoterapi mengarah pada reeducational of individual mencari persepsi dan pertobatan secara jelas, mengintegrasikan ke dalam kehidupan sehari-hari dan memagri perasaan sedih yang berasal dari pengalaman buruk di masa lalu. Sedangkan fungsi lainnya adalah bahwa psikoterapi dapat bertindak sebagai kuratif (penyembuhan), preventif (pencegahan) dan konstruktif (pemeliharaan dan pengembangan). Dengan demikian fungsi psikoterapi dapat dikembankan bukan hanya untuk seseorang yang mengalami kesulitan psikologis tetapi juga pengembangan diri untuk optimalisasi potensi yang dimiliki.

Tobat yang memiliki kombinasi dengan fungsi-fungsi kejiwaan dapat mengisi bagian lain dalam fungsi psikoterapi Islam. Hal ini dapat dipahami dikarenakan dalam proses pertobatan telah terbentuk berbagai fungsi positif kejiwaan yaitu:

1. Adanya keinginan untuk perubahan perilaku (kesadaran)

2. Terbukanya pintu evaluasi diri (pengakuan dosa)

3. Menguatnya perasaan positif (penyesalan)

4. Terbentuknya sikap hidup yang positif (komitmen)

5. Perubahan perilaku secara konsisten

Secara umum gangguan mental (psikologi) seseorang banyak disebabkan oleh (a) perbuatan maksiat; (b) pelanggaran terhadap hokum (aturan) Allah baik yang berkaitan langsung dengan Allah dalam ibadah mahdhoh, dengan sesame manusia dan lingkungannya (muamalah) maupun dengan dirinya sendiri (mendholimi diri); (c) kesalahan dalam persepsi dan kehendak serta mensikapi kehidupan (disorientasi). Gejalagejala gangguan mental yang ringan sampai berat merupakan proses berkelanjutan dari akibat dosa yang dilakukan akan mengakibatkan gangguan mental yang semakin berat dan kompleks.

Fungsi tobat dalam psikoterapi Islam memegang peranan penting dalam proses penyembuhan dan mengembalikan kembali potensi fitrah yang dimiliki seseorang. Tobat 
yang dilakukan dengan benar (nasuhah) dapat berfungsi sebagai:

1. Alat pembersih noda hitam dalam hati.

Pembersihan noda ini akan sangat membantu pemulihan mental-psikologis seseorang yang sedang mengalami gangguan (penyakit) mental. Hal ini dapat dipahami bahwa fungsi tobat dalam psikoterasi Islam memegang peranan penting dalamwa noda hitam dalam hati (qalb) inilah yang menjadi sumber munculnya gangguan penyimpangan pikiran, perasaan, perilaku seseorang sehingga dengan dibersihkan terlebih dahulu akan mengurangi noda dan dapat membantu proses pemulihan mental psikologis seseorang. Proses pembersihan awal ini dapat dilakukan dengan lisan (ucapan) memohon ampun kepada Allah dan dibarengi dengan aktivitas sholat tobat seperti yang dicontohkan Nabi.

\section{Penguat pikiran dan perasaan}

Proses pertobatan yang diikuti dengan kegiata pengakuan dosa (evaluasi diri) da penyesalan dapat menumbuhkan pikiran dan perasaan positif. Hal ini dapat terlihat dengan tumbuhnya optimism menjalani kehidupan, tidak putus asa, mampu mengenali dan menerima diri dengan lebih baik serta mampu berfikiran positif terhadap setiap kejadian. Tumbuhnya sifat seperti ini akan sangat membantu seseorang yang sedang menghadapi masalah atau gangguan mental dan ini merupakan langkah terbaik untuk mengatasi gangguan tersebut. Munculnya sifat positif tersebut dapat dikatakan sebagai kesemuhan tingkat awal para klien yang mengalami gangguan mental.

3. Pendorong berkembangnya potensi manusia

Tobat dapat merangsang seseorang untuk meingkatkan amal perbuatannya melalui evaluasi diri, pemetaan dan perencanaan kegiatan baik lainnya, baik yang pernah ditinggalkan maupun yang belum pernah dilakukan. Seseorang akan selalu mencari tambahan amal kebaikan untuk menutupi kesalahan (dosa) yang pernah dilakukan dan tidak ada hari tanpa menyempurnakan amal kebaikan. Kondisi ini dapat mengakibatkan terbukanya potensi diri yang selama ini tidak diketahui atau tertutup oleh perbuatan buruknya, sehingga memungkinkan akan melejitnya potensi diri yang dimiliki.[]

\section{G. DAFTAR PUSTAKA}

Al-Jauziah, Ibn Qayyim. Al-Da'wa alDawa': al-Jawab al-Kaafi li-Man Sa'ala 'an al-Dawa'

al-Syafi, Alih Bahasa Fauzy Bahresy. Jakarta: Serambi Ilmu Semesta, 2004.

Al-Ghazali, Imam. Mukhtashar Ihya' 'Ulumuddin,Cetakan I. Beirut: Muassah Al-Kutub Al-Tsaqafiyah, 1990.

Al-Hilali, Abu Usamah Salim bin 'Ied. Syarah Riyadhus Shalihin, Alih Bahasa. M.Abdul Ghoffar. Jakarta: Pustaka Imam Al-Syafi;I, 2005

Al-Maraghi, Ahmad Mustafa, Terjemah Tafsir al-Maraghi, Vol. 4. Semarang: Toha Putra, 1993

Al-Qozin, Sunan Ibn Majah, Jilid I. Mesir: Darul Fikr.t.t.

Al-Razi. Ruh dan Jiwa: Tinjauan Filosofis Dalam Perspektif Islam. Surabaya: Risalah Gusti, 2000.

Assamarqandi, Al-Faqih Abul Laits. Tanbihul Ghafilin, Alih Bahasa, Salim Nabhan. Surabaya: Al-Manar,1990.

al-Thusi, Khawajah Nashiruddin. Menyucikan Hati Menyempurnakan Jiwa. Jakarta: Pustaka Zahra, 2003.

Aziz, Muhaimin. Majalah Sufi, Edisi 28 Desember 2003.

Bahreisj, Hussein. Hadits Shahih: BukhariMuslim. Surabaya: Karya Utama, t.t.

Bertens,K. Psikoanalisis Sigmund Freud. Jakarta: Gramedia Pustaka Utama, 2006.

Daradjat, Zakiyah, Kesehatan Mental. Jakarta, Haji Masagung 1990.

Departemen Agama RI., Al-Qur'an dan Terjemahnya, Gema Risalah, Bandung, 1986.

Hamka. Tasawuf: Perkembangan dan Pemurniannya. Jakarta: Pustaka Panjimas, 1993. 
Hasan, Muhammad. al-Qur'an dan Pengobatan Jiwa. Yogyakarta: Bintang Cemerlang, 2001.

Jalaluddin, Psikologi Agama. Jakarta: Raja Graffindo Persada, 2001.

Jaya, Yahya. Peranan Tobat Dan Ma'at Dalam Kesehatan Mental. Jakarta: Yayasan Pendidikan Islam Ruhana, 1992

Imam An-Nawawi, Imam, dkk. Syarah Hadits Arba'in: Kompilasi Empat Ulama Besar. Jakarta: Niaga Swadaya,2008.

Kartono, Kartini.Kamus Psikologi. Bandung: Yayasan Pendidikan Islam 2000.

Lazarus, Richard S, Susan Folkman. Stress, Apprasial and Coping. New York: Springer, 1984.

MM., Sukanto.Nafsiologi, Suatu Pendekatan Alternatif Atas Psikologi. Jakarta: Integritas Press, 1985.
Sobari, Abdul Manan bin Muhammad. Keagungan Rajab dan Sya'ban. Jakarta: Republika, 2006.

Salim, Agus. Tauhid, Taqdir dan Tawakkal. Jakarta: Tinta Mas, 1960.

Shaleh, Qamaruddin dan Dahlan, AA. Asbabun Nuzul, Latar Belakang Historis Turunnya Ayat-ayat al-Qur'an. Bandung: Diponegoro, 1996.

Syarif, Adnan. Psikologi Qur'ani, Bandung: Pustaka Hidayah, 2002.

Thabbarah, Afif Abdullah Fattah, Dosa Dalam Pandangan Islam. Bandung: Risalah1986.

Wade, Carole \& Carol Tavris. Psikologi, Edisi 9, Jilid. Jakarta: Erlangga, 2007. 